This is an Open Access article, distributed under the terms of the Creative Commons AttributionNonCommercial-ShareAlike licence (http://creativecommons.org/licenses/by-ncsa/4.0/), which permits non-commercial re-use, distribution, and reproduction in any medium, provided the same Creative Commons licence is included and the original work is properly cited. The written permission of Cambridge University Press must be obtained for commercial re-use.

\title{
A Ritual Feature with Bell Beaker Elements in a Late Neolithic Hunter- Gatherer Campsite in North-Eastern Poland
}

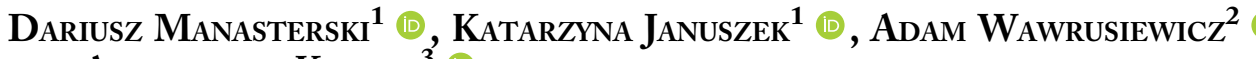 \\ and AleKsandra KLECHA ${ }^{3}$ \\ ${ }^{1}$ Institute of Archaeology, University of Warsaw, Poland \\ ${ }^{2}$ Podlaskie Museum, Biatystok, Poland \\ ${ }^{3}$ South-Eastern Europe Research Centre, University of Warsaw, Poland
}

The ephemeral nature of religious practices and rituals makes them challenging to trace in the archaeological record of Late Neolithic hunter-gatherer communities in central and eastern Europe. A ritual feature with Bell Beaker elements discovered in north-eastern Poland, a region occupied by huntergatherer groups of the Neman cultural circle, is thus exceptional. Its syncretic character indicates its role as a harbinger of wider cultural change that led to the emergence in this region of the western group of the Bronze Age Trzciniec cultural circle.

Keywords: Late Neolithic, hunter-gatherers, ritual feature, Bell Beaker set, north-eastern Poland, Neman cultural circle, Trzciniec cultural circle

\section{INTRODUCTION}

Rapid progress in scientific methods has opened new vistas for research, putting an array of modern analytical tools at the service of archaeologists examining behaviour that had previously been elusive. This is particularly true of 'irrational' practices, such as religious ceremonies, which leave little if any evidence in the archaeological record (e.g. Renfrew, 1994: 50-53). The issue is all the more important in the case of 'mute' prehistoric communities, such as hunter-gatherer groups, where the material evidence of their presence is sparse and scattered, and burial rites leave no or few tangible archaeological traces. Groups from the Neman cultural circle (sensu Manasterski, 2016: 21) in central and eastern Europe, still practising a hunter-gatherer mode of life in the Late Neolithic, are such an example. They occupied a region that was being penetrated in the Neolithic by groups of farmers and pastoralists, interactions with whom impacted local cultural processes of the local people. Site 6 at Supraśl in Podlachia (Figures 1 and 2A) constitutes one of the most 


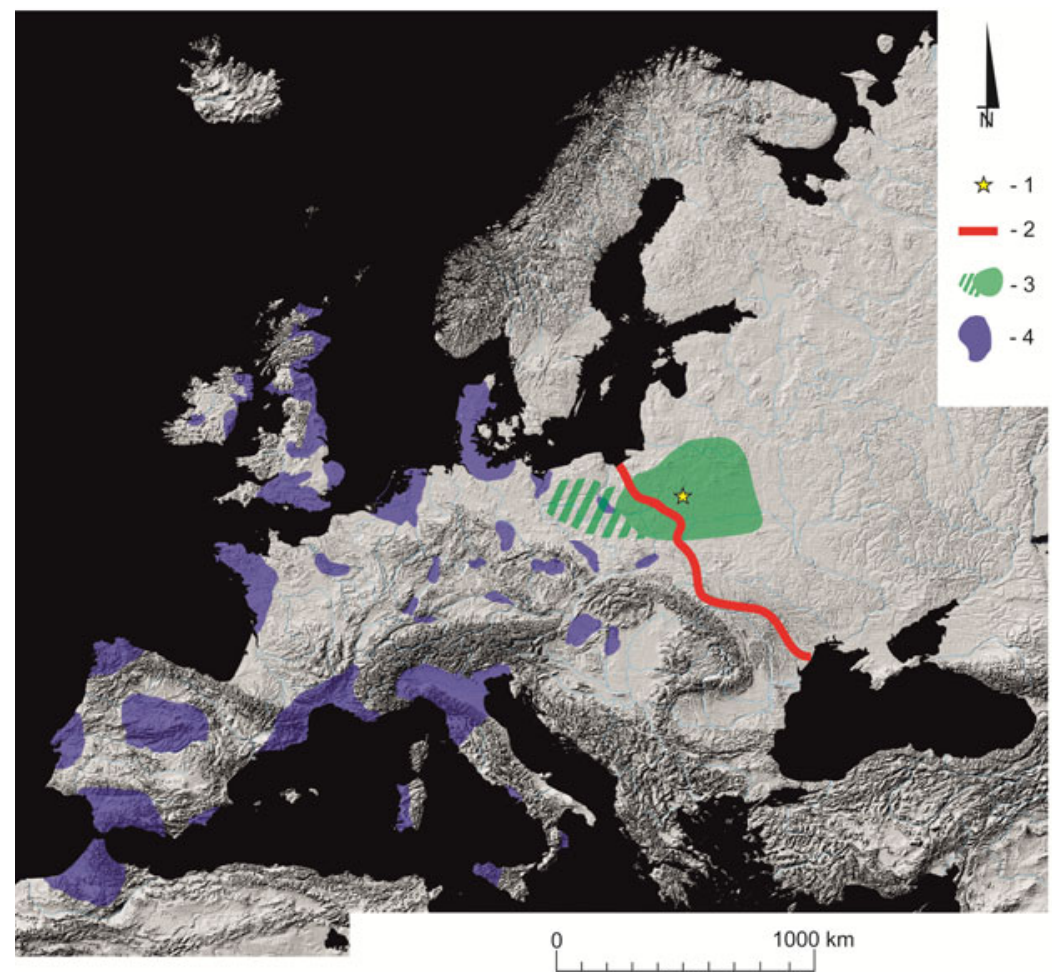

Figure 1. Location of Site 6 in Supraśl. 1: Site 6 at Supraśl; 2: Borderland between western and eastern Europe; 3: Neman cultural circle; 4: Bell Beaker phenomenon (sources: Józwiak, 2003: map 8; Wawrusiewicz et al., 2015: fig. 5).

interesting recent central-eastern European archaeological discoveries relating to the nature of these cultural interactions, including ritual practices

Podlachia, or Podlasie in Polish, is a geographical and historical region in north-eastern Poland on the border with Belarus, part of the wider North Podlasie Plain, one of the westernmost regions of eastern Europe (Kondracki, 2002: 236). Podlachia is distinguished by its continental climate and forms a border zone between the Western and Eastern European Plains, the former characterized by its Atlantic climate, the latter by its continental climate. Aleksander Kośko and Marzena Szmyt noted the key role this distinction in climate played in the
Neolithization of north-eastern Poland, as both an inhibitor and a stimulator (Kośko \& Szmyt, 2004: 81-82). It had serious consequences for the cultural make-up of the region, which remained a zone occupied by hunter-gatherer societies up to the beginning of the Bronze Age in the early second millennium BC. Traces of Neolithic farming and pastoral cultures have been found in Podlachia, but not in quantities that would indicate that the economic model based on hunting and gathering was significantly affected (Wawrusiewicz, 2011; Wawrusiewicz et al., 2015: 15-16).

The communities of the Neman culture at Site 6 in Supraśl belonged to the subNeolithic Neman cultural circle, which consists, apart from the classic Neman 

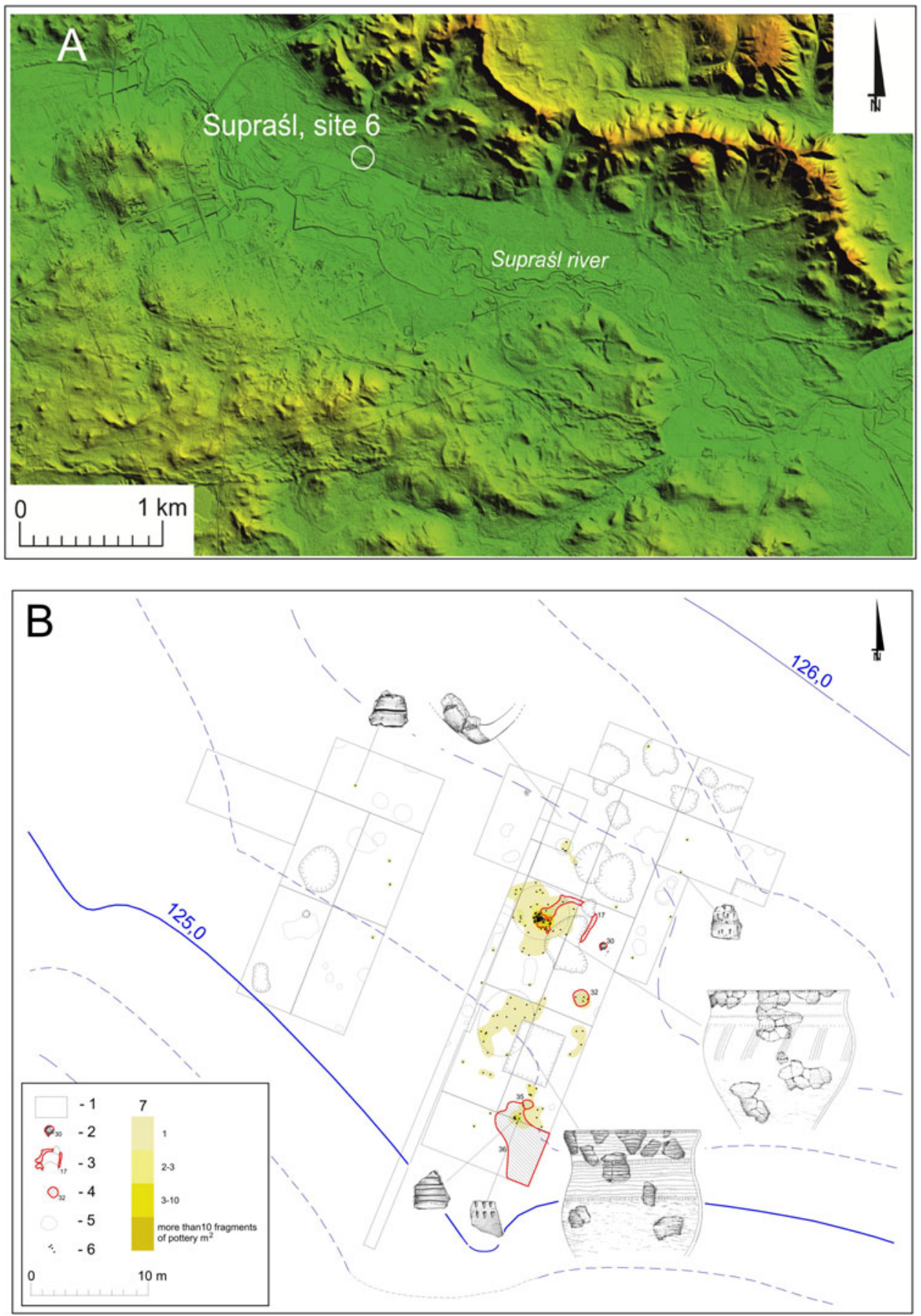

Figure 2. Supraisl, Site 6. A: Model of the relief around the town of Supraisl marking the location of the site; B: Site 6, excavated areas: trenches (1), stone hearth with ritual deposit Feature 30 (2), ephemeral shelter (3), domestic features (4), damaged area (5), Neman culture sherds (6), visualization of sherd clusters and density (7) (sources: Kwiatkowski, 2015: fig. 1; Wawrusiewicz et al., 2015: fig. 69). Reproduced by permission of the Podlachian Museum in Białystok. 
culture, of the Linin group in Masovia and the Zabie-Szestno group in Masuria, both in central north-eastern Poland (Manasterski, 2016: 21, fig. 2). These communities made pottery while still practising a hunting-gathering economy. In the Late Neolithic, they occupied the vast territories between the upper Pripet river and the Vistula, sporadically reaching the Noteć and Oder rivers in western Poland (Charnyavski, 2011a: 49; Józwiak, 2003: 189-95, map 11; Manasterski, 2016: 19). Their material culture reveals Neolithic cultural influences and an Early Bronze Age impact in its final phase, which would seem a natural consequence of human interaction. Ceramic vessels constitute the chief evidence of cultural diffusion in the Neman cultural circle (e.g. Kempisty, 1973, 1989: 313-16; Józwiak, 2003: 189ff.; Charnyavski, 2011b; Manasterski, 2009: 62-64, 2014a: 41-53, 2014b), hence they are a key factor for identifying the cultural components of groups influencing change. Other types of archaeological evidence have yet to be clearly defined (Józwiak, 2003: 69-76, 147, 151-53, 158-61; Manasterski, 2016: 19-21). Evidence of spiritual life in the form of ceremonial or ritual features is uncommon (Wawrusiewicz et al., 2017: 188). Feature 30 from Site 6 in Supraśl (Figure 2B) is one such extremely rare example. The context and the finds assemblage, coupled with results from archaeometric studies, suggest unique activities indicative of ritual practices.

In the Early Bronze Age, alongside other Late Neolithic and Early Bronze Age cultural units, including Bell Beaker elements, the Neman cultural circle fed into the formation of the western part of the Trzciniec cultural circle (sensu Makarowicz, 2010: 437). This latter represents the cultural community of the borderland between western and eastern Europe (Makarowicz, 2010: 24, 387).

\section{Materials ANd Methods}

\section{Materials}

The feature known as Feature 30 at Site 6 in Supraśl formed an integral part of a Late Neolithic settlement and ritual complex (Figures 2B and 3; Wawrusiewicz et al., 2015: 90-94). It consists of a hearth, within which a bag made of unidentified organic material containing an array of ecofacts and artefacts was found. The only evidence of this 'pouch' was a ring of darker sand surrounding the contents (Figure 4B).

The hearth (Figure 4A), which measured $0.50 \mathrm{~m}$ in diameter, was constructed of pebbles. These stones were fire-cracked. The deposit inside it, which must have been contained in a bag, included yellowish sand distinct from the surrounding sand matrix, heavily fragmented burnt bones, five small sherds of differently ornamented ceramic vessels, a small piece of metal plate with a thick patina, an amber pendant, and three flint tools.

The yellow sand (Figure 4) was clearly different from the surroundings in terms of grain structure and homogeneity. It must have come from elsewhere, from a location yet to be identified. The bones (presumed to be animal, but see below) mixed with it, as well as the ceramic sherds, flint artefacts, and amber pendant suggest that it formed an integral part of the deposit. The bones were the only organic macro-remains recovered, consisting of a small quantity of heavily fragmented burnt bone weighing $39.6 \mathrm{~g}$, the larger fragments being cracked and deformed (Figure 5A). The strong fragmentation, porosity and white colour indicate burning at high temperatures of around 900$1000^{\circ} \mathrm{C}$. Identification to species, possible only for a few larger fragments, determined the presence of domestic animals, i.e. cattle, goat/sheep, and pig (Gręzak, 


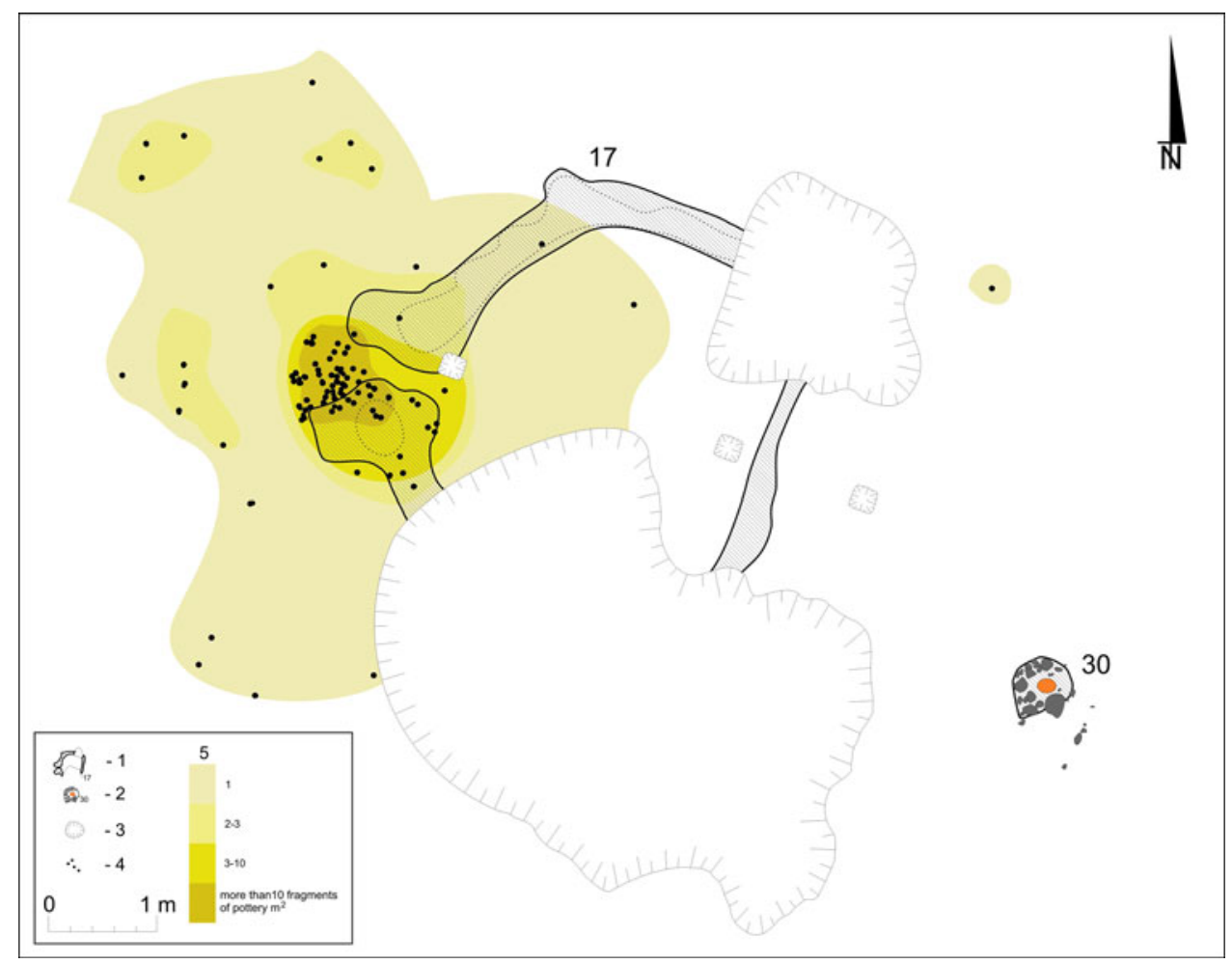

Figure 3. Suprásl, Site 6. Ephemeral gully for shelter (1); stone hearth with ritual deposit Feature 30 (2); damaged area (3); pottery sherds (4); density of sherd clusters (5).

2015: 247). Nothing can be said about the other bones; it is not even certain whether they all belong to animal species or whether some bones could be human.

Five small sherds from decorated vessels were found, each with a different motif. They were probably brought to the site from elsewhere because the excavated part of the site yielded no other fragments belonging to these pots (Figure 2B). The varying surface condition of these sherds indicates that they had lain in different contexts before being deposited in the feature. One fragment, identified as a bell beaker, had remains of a white substance (calcium carbonate) adhering to the break and in the grooves of the combimpressed decoration (Figure $5 \mathrm{~B} 1$ and C). A small piece of a heavily patinated metal plate, approximately $9 \mathrm{~mm}^{2}$, was stuck to the inside of this fragment (Figures 5C and 8C).

A pendant (Figure 5D) made of a natural lump of amber had a threading hole measuring $1.5 \mathrm{~mm}$ in diameter, drilled from both sides (Figure 8B). The irregular trapezoidal shape of this piece was slightly modified.

The three flint artefacts are a perforator (Figure 5E1), a burin (Figure 5E2), and the tip of an arrowhead (Figure 5E3). The first two are made of so-called chocolate flint, which does not occur naturally in the region, its outcrops being located on the north-eastern fringes of the Holy Cross Mountains further south in Poland (Budziszewski, 2008: 49-87). Their surface preservation differs, the perforator having a glossy sheen and the burin bearing evidence of overheating. The arrowhead 

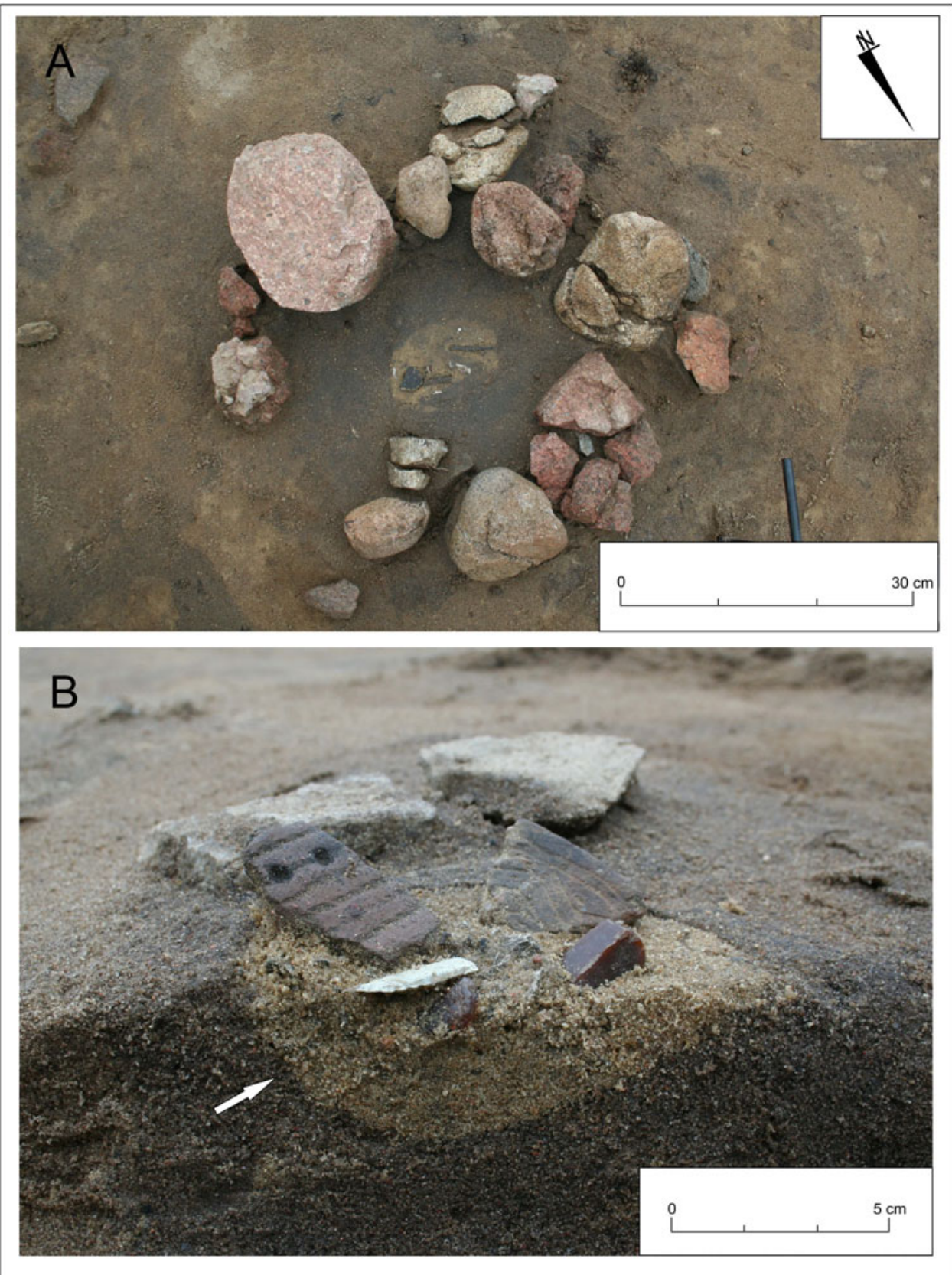

Figure 4. Stone hearth with ritual deposit Feature 30 in plan $(A)$ and in section during excavation (B); the white arrow marks the traces of an organic container ('pouch') (source: Wawrusiewicz et al., 2015: figs 51, 53). Reproduced by permission of the Podlachian Museum in Białystok.

fragment is covered with a white patina that makes it impossible to identify the raw material. Given these differences in surface preservation, the three artefacts must be considered as having been collected from different contexts. 

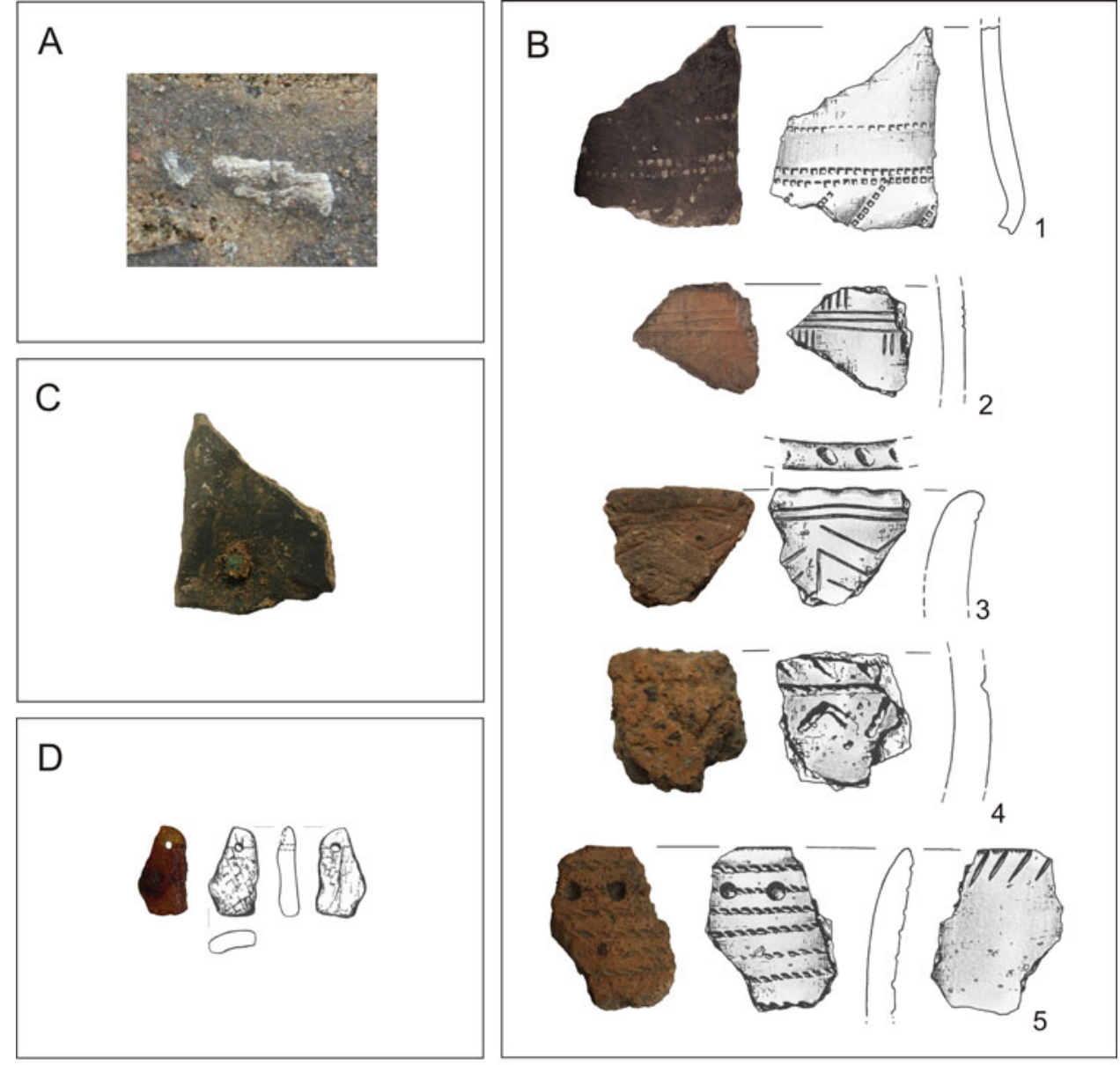

$E$
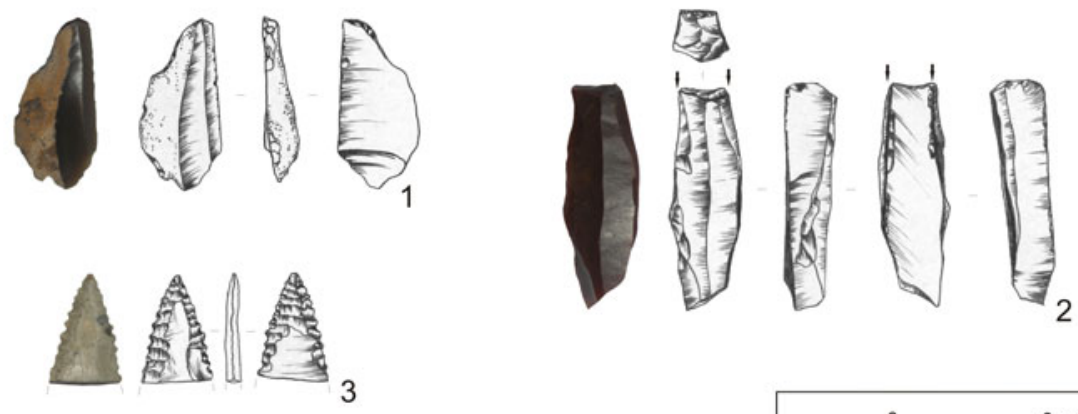

3

Figure 5. Artefacts from the hearth Feature 30. A: burnt bone. B: pottery sherds: 1-3: Bell Beaker pottery; 4-5: Linin Group pottery. C: fragment of a metal plate attached to the inside of a bell beaker. D: amber pendant. E: flint artefacts (1: perforator, 2: burin, 3: arrowhead fragment).

Feature 30 was located approximately $2 \mathrm{~m}$ south-east of a gully that encircled an area of $25 \mathrm{~m}^{2}$, interpreted as an ephemeral shelter-like structure with an approximate diameter of $4.5 \mathrm{~m}$. This gully had clear evidence of posts at its 


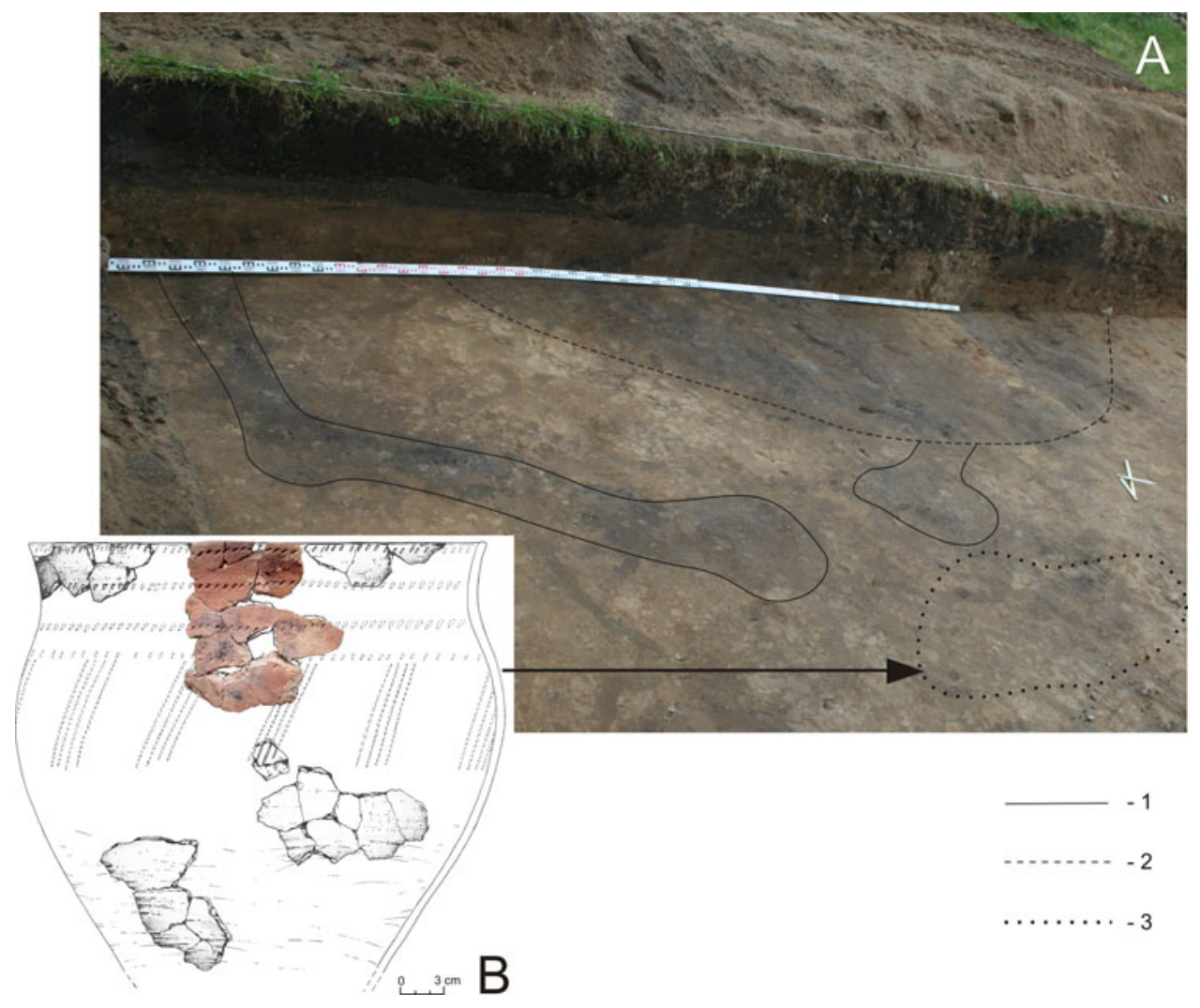

Figure 6. Concentration of vessel fragments in front of the entrance to the 'shelter'. A: outline of the ephemeral shelter gully (1), damaged area (2), concentration of sherds from an S-shaped vessel (3). B: vessel reconstruction based on sherds from the cluster.

base and an entrance at the west (Figure 3, no. 17 and Figure 6A). The feature was partly damaged by a modern disturbance. Numerous sherds from an S-shaped vessel (Figures $6 \mathrm{~B}$ and $7 \mathrm{~B}$ ) were found concentrated in a small area just outside the presumed entrance to the 'shelter', while further fragments of this vessel were scattered around it (Figure 3, no. 4 in legend).

The area of the settlement and ritual complex excavated at Site 6 did not yield any organic remains suitable for radiocarbon dating. Therefore, the dating of the site to the second half of the third millennium $\mathrm{BC}$ is based on the conventional pottery typology developed for the region (Wawrusiewicz et al., 2015: 160-62).
The formal characteristics of the broken vessel found in front of the entrance to the shelter-like structure have been used to date this feature. The technology, form, and ornamentation of the pot find many parallels in the ceramics of the Neman culture of the Neman river basin, specifically the Dobryj Bor type (Charnyavski, 1979: fig. 17 nos 3, 10, 13, fig. 18 nos 1 , 11-14; Lakiza, 2008: pl. 18 no. 6) dated from the second half of the third to the beginning of the second millennium $\mathrm{BC}$ (Charnyavski, 1979: 78). Our pot also closely resembles vessels classified as group IV (a stylistic Neman culture pottery grouping) of the well stratified site at Grądy-Woniecko (Wawrusiewicz et al., 


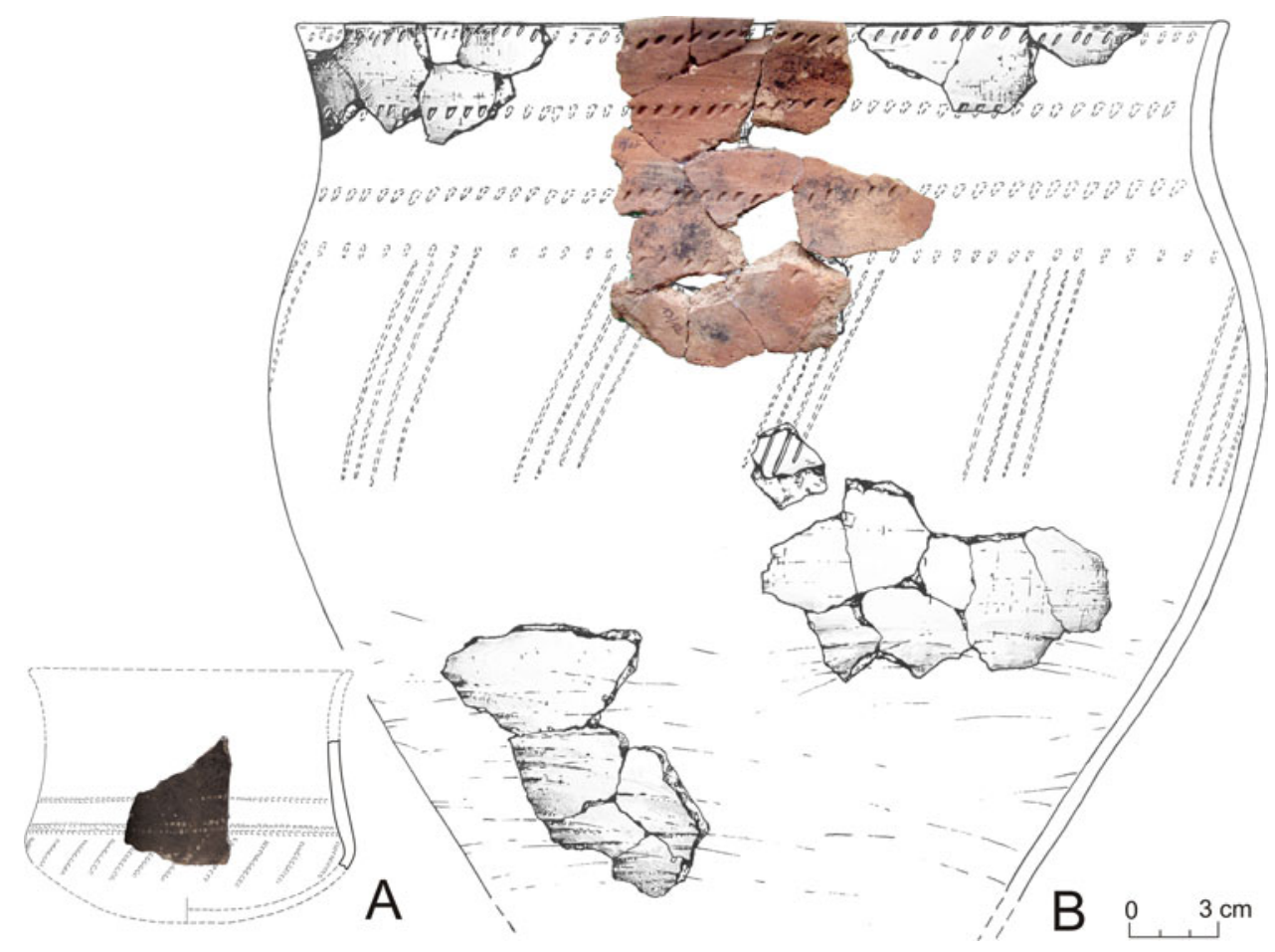

Figure 7. Reconstruction of the decorated vessels from Suprasl Site 6. A: bell beaker from the ritual deposit; B: S-shaped pot recovered in front of the entrance to the 'shelter'.

2017: 167-68). The chronological placement of this group in the second half of the third and beginning of the second millennia $\mathrm{BC}$ has been established chiefly by seriation, supplemented by radiocarbon dates. This concurs with earlier determinations made by Belarusian researchers (Wawrusiewicz et al., 2017: 175-76). It is also consistent with the results of comparative analyses of two fragments of vessels with cord ornament from the deposit (Figure 5B: 4-5), especially a sherd with an impressed cord pattern linked to deep dots and incised decoration on the inside of the vessel under the rim (Figure 5B: 5). Vessels with such decoration fit the stylistic convention of group VIc identified in the material from Grądy-Woniecko (Wawrusiewicz et al., 2017: 171, fig. IV.23) and are dated to the end of the third and beginning of the second millennium $\mathrm{BC}$.

\section{Methods and Results}

A series of archaeological (including chronological and cultural identification as well as typological and technological classification) and archaeometric methods were used to examine the finds assemblage from Site 6 at Supraśl (Wawrusiewicz et al., 2015). The specific properties of the objects were determined as follows.

The stones from the hearth (Figure 4A) were analysed by non-invasive petrography, examining under stereoscopic microscope the rock surface immersed in water (Krajcarz, 2015: 253). The analysis identified: Stockholm granite, Äland quartz porphyry, and Ragunda granite. Outcrops of these rocks are known on the northern Baltic shores. These are indicators of erratic rocks, from glacial/fluvioglacial deposits, also recorded in northern Podlachia. They 
bear traces of abrasion without aeolian polishing and glacial erosion, which denotes a riverine or alluvial provenance (Krajcarz, 2015: 259-61). The most likely scenario is that the pebbles were brought to the site because no similar stones could be found within the $1000 \mathrm{~m}^{2}$ of the site excavated at Supraśl or in the nearby valley of the Supraśl river. The pebbles around the hearth were heavily cracked and crumbling, which indicates that they had been subjected to high temperatures for less than four hours (Krajcarz, 2015: 261-62). Ethnographic sources suggest that this time is too short for natural cooling to be responsible for such damage, but it can be achieved by pouring water on the pebbles while still hot. Potters from nearby western Belarus were still using this technique for crushing rock in the first half of the twentieth century (Hołbowicz, 1950: 33).

The metal plate fragment was subjected to metallographic analysis (Wawrusiewicz et al., 2015: 108-09). Given the state of preservation and small size of the artefact, $\mathrm{X}$-ray fluorescence was the only analysis that could be undertaken. Chemical composition analyses of the metal, including Energy-dispersive X-ray spectroscopy (EDX-SEM) and a graph showing the spectrum of metal peaks, were conducted with a Tescan Vega scanning microscope. The metal plate was chiefly made of copper and tin (Figure 8C), which points to bronze as an alloy. However, spot analyses revealed different ratios of the two metals, perhaps indicating soldering of two surfaces or edges rather than an alloy. If so, it would be one of the oldest known examples of the technique (Wawrusiewicz et al., 2015: 109, fig. 62). A small hole, c. $1 \mathrm{~mm}$ in diameter, can be discerned in the $\mathrm{X}$-ray image of the artefact (Figure $8 \mathrm{C}$ ). It could suggest that the piece formed part of a larger object, perhaps a pendant. It is differentiated from contemporary finds from other regions of central and eastern
Europe due to it being one of the oldest metal artefacts discovered in northern Podlachia and apparently being copper soldered with tin.

Infrared spectroscopy (IRS) was used to examine the amber pendant. It revealed that the pendant was made of succinite (Baltic amber); the diagnostic bands indicate strong weathering of this raw material (Kwiatkowska, 2015: 330, fig. 1). Microwear trace analysis coupled with experimental research indicated that a tool with a sharp edge (possibly a metal knife, most probably a copper alloy, rather than flint; Popkiewicz, 2016: 57-59) was used to modify the shape of the object (Popkiewicz, 2016). The hole was drilled with a copper-alloy drill (Popkiewicz, 2016: 59). The object is an asymmetric pendant belonging to sub-group $2 \mathrm{~A}$ in Mazurowski's classification (Mazurowski, 1983: 31, table 2). Pendants with drilled suspension holes, made of natural or only slightly modified lumps of amber, appear for the first time on the Polish Plain in the Early Bronze Age and are linked to the Iwno and Únětice cultures (Bukowski, 2002: 31-32). However, the drilling technique using a metal drill is completely unknown in central and eastern Europe at this time. This kind of precise perforation with a metal drill was an Early Bronze Age technological improvement in amber processing and was used in the British Isles and the Mediterranean region (Mazurowski, 1983: 113).

The flint artefacts were examined for use-wear traces using a metallographic microscope (Pyżewicz, 2015: 304). Their analysis revealed a variety of postdepositional changes that made it difficult to identify their function. In the case of the arrowhead, a characteristic 'impact' mark (Figure 8D) and weak linear traces on one of its surfaces suggest that it was used either for hunting or in combat (Pyżewicz, 2015: 304-05). The flint 

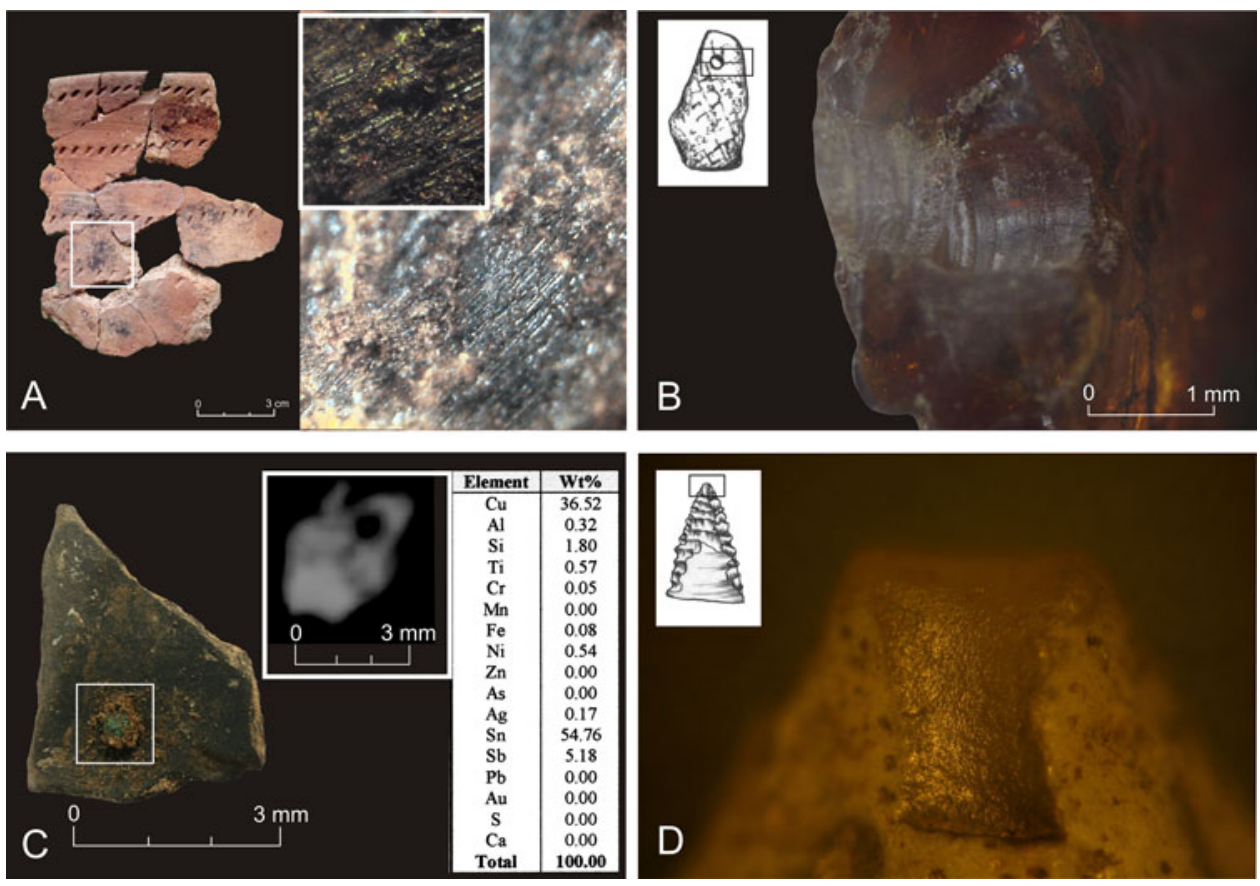

Figure 8. Selected images from analyses of artefacts from Suprásl Site 6. A: wood tar traces on the surface of the $S$-shaped pot recovered in front of the entrance to the 'shelter' under magnification (200x and 120×); B: traces of drilling with a metal tool of the threading hole in the pendant; C: fragment of a metal plate in an X-ray image and analyses of its chemical composition; D: impact marks on the tip of the arrowhead (magnification >50x) (sources: Pietrzak, 2015: fig. 2, 6; Pyżewicz, 2015: fig. 5, 1A; Wawrusiewicz et al., 2015: figs 59-62, 71).

artefacts are not very distinctive, either chronologically or culturally; although the burin is close to Late Palaeolithic examples in terms of shape and the raw material employed (Schild et al., 1975: fig. 15.1).

The pottery sherds from the 'shelter' entrance were subjected to a series of analyses. The organic remains on the vessel wall were examined under a polarizing optical microscope (PZO) in low magnification. A detailed classification of the samples was performed using a polarization microscope coupled with a Boëtius PHMK 05 apparatus with a heating table. ThinLayer Chromatography (TLC) was undertaken to identify the substance contained in the samples. Supplementary techniques involved infrared spectrophotometry (IR) and measurement of the electron paramagnetic resonance (EPR) spectra (see Pietrzak, 2015: 284-85). As for the organic temper in the fabric of the ceramics, it was examined with a gas chromatographer (GC Agilent Technologies $6890 \mathrm{~N}$ ) coupled with a mass spectrometer (MS, 5973 Network Mass Selective Detector). The interpretation of the fractional analysis results was based on a determination of fatty acids and biomarkers using proportions proposed by English and American researchers (see Rosiak \& Kałużna-Czaplińska, 2015: 275, 279-80).

The sherds belonged to a large Sshaped pot with a rim diameter of $c$. $33 \mathrm{~cm}$ and a wall thickness of just $0.5 \mathrm{~cm}$ (Figures 6B and 7B). The fabric was tempered with selected crushed granite 
pebbles. The upper part of the vessel was ornamented with a pattern of repeated stamped motifs and tarred. The form, proportions, technique, and decoration bring to mind Late Neolithic Neman culture containers, identified with the Dobryj Bor type (see Charnyavski, 1979: fig. 17 nos 3, 10, 13, fig. 18 nos 1, 11-14; Lakiza, 2008: pl. 18 no. 6). Regarding the decoration, the segmented composition consisting of diagonal lines engraved below a set of horizontal motifs is exceptional. The vessel is a typical Neman culture product, but the decoration resembles the ornament on a fragment of a bell beaker (Figure 7) found in the 'pouch' deposited in the nearby stone hearth.

Physico-chemical analyses of the fragments of the S-shaped pot revealed evidence of pine tar on its surface (Figure 8A). Tar production was typical of the communities of the Neman cultural circles in north-eastern Poland (Pietrzak, 2015: 294-95, 2017: 312-14). Testing for organic substances preserved in the vessel body revealed only plant products (Rosiak \& Kałużna-Czaplińska, 2015: 280). A plant steroid, a morphine derivative, and ricinoleic acid all confirmed the presence of plants. These substances indicate that the pot was intended for either making or storing a psychoactive substance of vegetal origin (Rosiak \& Kałużna-Czaplińska, 2015: 280-81).

Of the five vessels from which the sherds from the deposit inside the hearth were derived, three had typical features of Bell Beaker pottery (Figure 5B: 1-3), whereas the other two combine components of the Neman and Corded Ware culture pottery (Figure 5B: 4-5). These syncretic forms are characteristic of the Linin and ZąbieSzestno groups. Vessel form was identifiable in the case of only one bell beaker (Figure 7A). The fabric consisted of clay tempered with mineral substances (sand and crushed rock) in proportions and fractions that varied for each vessel. The bell beaker alone contained mica as temper in the fabric. Lipid residue analyses were not performed, as these would have required the total destruction of these small sherds.

The state of preservation of the various artefacts found in the 'pouch' indicates that they came from different predeposition contexts. Their post-deposition context did not affect their properties, nor did the high temperature in the hearth above the finds, as attested by the amber pendant which does not show any effects of thermal influence. Based on the analyses performed, we argue the material within the 'pouch' was an intentional assemblage. Although the materials were quite variable and fragmentary, they show signs of careful curation, as can be seen in the smoothed edges of the ceramic sherds or the choice of three flint items of very different origin.

The results of the various analyses performed on the ecofacts and artefacts indicate that the selection of the objects placed in the 'pouch' was intentional. We further want to tentatively link this pouch deposit to the vessel recovered in front of the shelter, which lipid residue analysis revealed as having contained a narcotic substance. This pot was decorated in a manner that recalls-and perhaps citesone of the sherds of pottery in the pouch deposit. It may therefore have been used in the same practices as the materials found under the hearth, which we link to ceremonial rites.

\section{Discussion}

A typical hearth at first glance, Feature 30 from Site 6 at Supraśl nevertheless contained a unique deposit, comprising a number of objects that were exotic in the Podlachia region. The assemblage is homogeneous, although it is possible to 
distinguish a number of cultural components that differ from the Neman culture material recovered on the site as a whole.

Three of the five pottery sherds represent Bell Beaker pottery, while two are characteristic of the Linin and ZąbieSzestno groups, which also had a good measure of Bell Beaker influence (see Manasterski, 2016: 55-71, 83-90, figs 11-28). All the sherd breaks are smooth, but the degree of surface erosion varies. Only one fragment bears the remnants of calcium carbonate. These characteristics indicate that the pots were already broken for some time before being placed in the 'pouch' and derived from different, not yet identified contexts. Fragments belonging to the same vessels were not found anywhere else in the excavated part of the site, while the smoothed edges of the sherds suggest that they had been subjected to movement for a while. The three other objects in the deposit are neither culturally nor chronologically diagnostic. Two are made of chocolate flint, which is an exotic raw material in Podlachia. However, the burin has parallels among Late Palaeolithic communities who imported this raw material (Schild et al., 1975: fig. 15.1). The incomplete patinated arrowhead fragment is difficult to compare with fully preserved examples recorded in the material culture of various Late Neolithic and Early Bronze Age groups. The evident surface damage on these artefacts from different pre-depositional factors, and the morphological and material resemblance of one of the pieces to a Late Palaeolithic object, suggest that the artefacts came from different contexts, for instance as surface finds from other sites.

Amber and metal are completely unheard of in Podlachia at the end of the Neolithic and the beginning of the Bronze Age. The amber pendant is typical of the Early Bronze Age Iwno and Únětice cultures, but the drilling technique of the suspension hole, using a metal borer instead of a flint drill, is unusual. The metal itself, a piece of copper and tin, is equally exotic in this region and in the entire Neman cultural circle. The remains of domesticated animals are unusual among the finds from sites of the Neman cultural circle in northern Podlachia. Indeed, if the unidentifiable burnt bones also included human remains, the bone assemblage might have originated in a cremation burial in which animals were burnt together or commingled after burning with a human body.

The evidence for burial rites of the Neman cultural circle is too limited to fully characterize typical customs. Only a few significantly different burials have been found to date (see Manasterski, 2009: 143-44; Wawrusiewicz et al., 2017: 52-58). Nonetheless, cremation is not an unknown rite in the Neman culture, having been identified at Site 1 in GrądyWoniecko in the valley of the Biebrza on the northern Podlachia Plain. Burnt bones with grave goods in the form of flint artefacts and ochre were discovered in one of the funerary features there (Wawrusiewicz et al., 2017: 55). The few bones that could be identified belonged to a human and to a deer or elk (Makowiecki, 2017: 287; Więckowski, 2017: 286). Numerous concentrations of burnt human and animal bones were recorded from this site's cultural layer, accompanied by Neman culture ceramics and flint. The excavators have suggested that it was a cremation site (Wawrusiewicz et al., 2017: 56-57). These finds could indicate that burnt human and animal bones occur together in the context of funerary rites, but the animal bones were exclusively those of wild species at Grądy-Woniecko. It would constitute a significant difference between the burnt bones of domesticated animals from the Supraśl feature and other finds of a funerary nature from the Neman cultural circle. 
The artefacts from the Supraśl deposit that can be attributed to a specific cultural unit are few. The Bell Beaker ceramic fragments are recognizable, but the other components are either syncretic in appearance (two pottery fragments of the Linin and Ząbie-Szestno group) or intercultural elements (the amber pendant and flint artefacts). Most, nonetheless, refer to the Bell Beaker set. Such artefacts, found in male burials, are considered to be status markers (Renfrew, 2001: 122). The core version of the set includes a bell-shaped beaker with decoration in zones (or metopes and zones), occasionally found together with other similarly decorated pots, archery items, a copper tanged dagger or small flint daggers, button beads made of bone with a $\mathrm{V}$-shaped threading hole, and gold and/or amber objects (e.g. Burgess and Shennan, 1976; Shennan, 1986; Garrido-Pena, 2007: fig. 1; Heyd, 2007). The distribution of the set is linked to innovations introduced among local European communities (Kleijne, 2019: 194). The spread is thus a dynamic process, regionally specific, but retaining certain similarities (Czebreszuk, 2001: 46, 140; Turek, 2013: 9).

The assemblage of exotic artefacts from the Supraśl deposit shows many symbolic similarities with objects found in Bell Beaker graves, especially in the choice of raw materials, less so in their form. The Supraśl items consist of single pottery sherds (including a bell beaker fragment) instead of whole vessels, amber in the form of a pendant instead of the button beads with $\mathrm{V}$-shaped hole common in the eastern provinces, a copper and tin metal plate instead of copper or gold artefacts, and a fragment of a flint arrowhead instead of a whole exemplar, all typical of the set, alongside burnt bones that are encountered in cremation rites in different areas within the reach of this cultural phenomenon. The nearest analogy for the
Podlachia assemblage is a Bell Beaker feature with amber ornaments, flint artefacts, and cremated human bones without pottery discovered at the site of Solbakkegard IV in Denmark (Nicolas, 2017: fig. 5b.5). A Bell Beaker deposit recovered at La Calzadilla (Valladolid, Spain) has a different significance. It contained fragments of broken vessels, food remains in the form of bones of domesticated animals, two human ribs, stone and bone tools, and the skull of an aurochs modified before deposition and interpreted as an ancestral symbol that was ultimately buried during the ceremony conducted at La Calzadilla (Liesau von Lettow-Vorbeck et al., 2014).

Following a cognitive approach (see Hodder, 1987; Renfrew, 1994: 51-52; Minta-Tworzowska, 2012: 143-58) and studies in cultural anthropology and archaeology, defining and explaining concepts of symbols and ritual behaviour (e.g. Orphanides, 1990; Renfrew \& Bahn, 1991: 359-60; Burszta, 1998: 101-19; Insoll, 2011), the characteristics, properties, and archaeological context of the Site 6 assemblages can be interpreted as ritual deposits. We suggest that the selection of material that was not native to Podlachia (a region characterized by the Neman culture) was intentional. The deposition appears to have been symbolic and ritual, not practical and utilitarian. Signs and symbols exist only because they are produced and reproduced by people who have a deep knowledge of their nature (Orphanides, 1990: 15). Moreover, a symbol refers to any object that may serve as a carrier of ideas (Geertz, 1992: 503). The placement of the Supraśl objects in a 'pouch' together with river sand and the deposition of the container in a hearth argue in favour of this interpretation. The choice of artefacts for this purpose was also specific, as the items came from different locations and contexts. Some are 
fragmented (pottery sherds, a piece of metal plate, burnt bones) regardless of where the fragmentation took place; exotic raw materials, such as amber, chocolate flint, and metal, are also present. These characteristics must have had a symbolic significance, motivating the choice of objects assembled. Evidence of similar behaviour, in the form of fragmented pottery sherds, burnt human and animal bones, amber beads, and arrowheads made by exotic flint, has also been recorded in ritual and funerary Bell Beaker features from northern Podlachia (Supraśl, Site 3, Features 1, 2, 5, 6; Wawrusiewicz et al., 2015: 44-60, 164; Manasterski et al., In press).

The selection of artefacts, chosen for their diverse origins, exotic character, peculiarity, and symbolic meaning, is indicative of a special, ritual significance. The objects, which are reminiscent of the Bell Beaker phenomenon and its specific cultural set, bring to mind associations with funerary rites (Burszta, 1998: 104). However, the presence of syncretic vessel sherds and burnt animal bones also points to links with the funerary rites of the Neman cultural circle known from GrądyWoniecko (Wawrusiewicz et al., 2017: 56-57, 188-89). Analyses of the pottery found in the context of funerary practices from that site uncovered traces of morphine derivatives (Wawrusiewicz et al., 2017: 188, 301) similar to the traces found in the vessel from in front of the 'shelter' at Site 6 in Supraśl.

The data point to a funerary rite containing two cultural components: allochthonous connected with the Bell Beaker, and autochthonous deriving from the Neman cultural circle. The syncretic rites evidenced by these material remains should be considered as representing a peculiar diffusion of beliefs that continued to evolve and which are still visible in Early Bronze Age communities of the western branch of the Trzciniec cultural circle.

Evidence of similar behaviour was noted in a continuation of ritual elements in successive deposits at sites such as Skrzeszew and Pass in Masovia (Januszek \& Manasterski, 2012; Manasterski \& Januszek, 2017), within the area of the Linin group, which forms part of the Neman cultural circle. The deposits are, however, not identical, reflecting the changes that took place over time and in a different cultural environment. The Skrzeszew feature was not a hearth, but a small pit with a pointed base. Its fill consisted of river sand and heavily fragmented charred plant remains originating from a hearth (redeposited oval chunks of pine and alder wood charcoal; Michniewicz, 2012). A collection of artefacts was recovered near the pit's base: single sherds from eight different ornamented vessels, fifteen flint artefacts with different degrees of erosion on their surface, sections of bronze wire, and fragments of two amber beads (a cylindrical bead and a trapezoid pendant). The pottery included syncretic vessels of the Linin group with components of the Neman cultural circle, Bell Beakers, post-Corded Ware, and early Trzciniec cultural circle. The largest sherd in the assemblage came from a bellbeaker-shaped vessel decorated with a quasi-band-and-metope motif (Januszek \& Manasterski, 2012: 116, pl. I). The flint forms a group of artefacts whose surface preservation indicates diverse provenances before their ultimate deposition in the feature (Januszek, 2015: 116-22). Among them is an arrowhead and two specimens of exotic chocolate flint alongside items made of local erratic flint (including two examples modified by high temperatures, one overheated and the other burnt through).

The Skrzeszew feature is similar to Feature 30 at Supraśl in that the context is 
connected with a hearth. As for the pottery, both features reveal the same choice of single sherds from ornamented vessels, with similar decorative components. The assemblage of flint artefacts is similar but larger, the similarity being chiefly based on the presence of a complete arrowhead, two items of rare chocolate flint and overheated and burnt exemplars. The similarity is also clear in the different post-depositional changes that reflect the diverse pre-depositional contexts of specific objects. Amber, was present in both features, including a trapezoid pendant. Such pendants are mostly known from burials of the Iwno culture and, to a lesser degree, the Únětice culture (Januszek \& Manasterski, 2012: 129). The drilling technique used to make the pendant's perforation is what mainly differentiates the Skrzeszew from the Suprasil pendants, the former having been drilled with a flint tool. Finally, both features contained a metal artefact: the Skrzeszew item is a fragment like the piece from Supraśl but made of classic bronze.

There are fewer similarities between the Supraśl feature and a small pit discovered at Pass (Manasterski \& Januszek, 2017). It contained a vessel placed upside down and a deposit of river sand and three flint artefacts. The vessel was a small S-shaped pot, resembling a slender bell beaker, decorated in its upper part with a quasi-bandand-metope ornament (Manasterski \& Januszek, 2017: fig. 2). The ornamental motifs, their composition and disposition, correspond largely to the largest sherd from the Skrzeszew deposit. While already characteristic of the Trzciniec cultural circle, it still recalls bell beakers in its morphology and style. The flint artefacts include two made of local erratic flint and one fragmentary piece of chocolate flint, all from different contexts. The pieces of local flint are paralleled at Skrzeszew, whereas chocolate flint artefacts are found in earlier features.
The key difference between the small pit at Pass and earlier features at Supraśl and Skrzeszew is that a complete vessel made of non-organic material was placed in the pit. There are no traces of a hearth or burning in the Pass feature. The assemblage did not include amber artefacts, metal objects, or individual pottery sherds. The flint did not include an arrowhead. Thus, the Pass feature, the most recent among our three examples, may be a weaker reflection of an act that had become symbolic: making this feature was merely a manifestation of being part of a community, whereas it had once been performed as an expression of 'living' values (Burszta, 1998: 114-15).

The artefacts made of non-local raw materials found at Supraśl, especially those demonstrating the use of an advanced technology (use of metal drills, soldering) do not recur in the local community, most probably because there was no access to either copper or bronze. The earliest evidence of local bronze production in Podlachia comes from Suraż, a site connected with the Late Bronze Age Lusatian culture (Dąbrowski, 1997: 167, map 11). Baltic amber was also not easily accessible in this region, hence the absence of amber artefacts from Neman culture sites in Podlachia. The only innovative element incorporated into this cultural circle is Bell Beaker pottery, chiefly its decorative style, less so its vessel shape, and hardly any elements of its production techniques. The initial stage consisted of more or less successful imitations of Bell Beaker ornamentation made according to local custom; the fragment found in front of the 'shelter' at Supraśl is such an example. This later evolved into a specific style combining a mixture of decorative components from Bell Beaker and other Late Neolithic and Early Bronze Age cultural entities. This led to the emergence of syncretic vessels described as 'proto-Trzciniec', which 


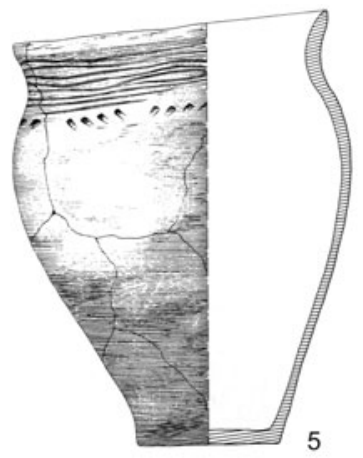

about $1600 \mathrm{BC}$

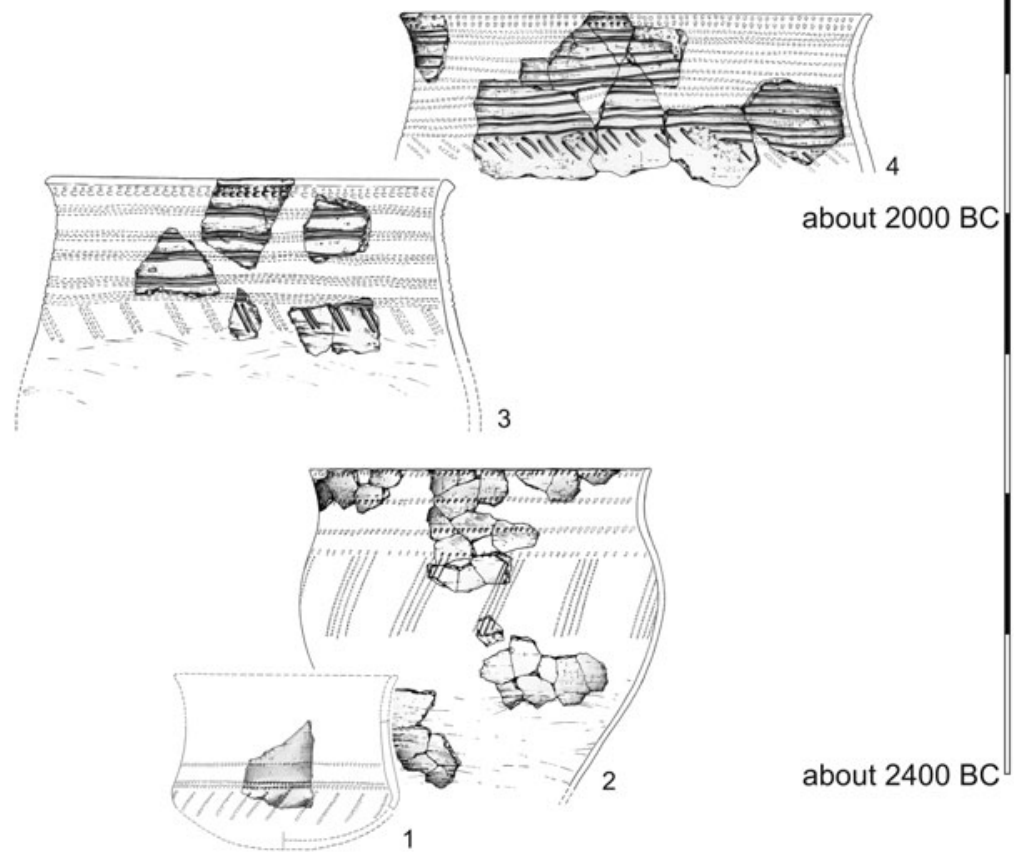

Figure 9. Possible adaptation and transformation of the Bell Beaker style in the Neman cultural circle into the Trzciniec cultural circle in northern Podlachia. 1: bell beaker from Site 6 at Suprasl; 2: Sshaped pot of late Neman culture from Site 6 at Supraśl; 3-4: proto-Trzciniec vessels from Site 1 at Grądy-Woniecko; 5: Trzciniec culture vessel from Site 1 at Strękowa Góra (sources: authors (see Figure 7); Bugaj, 2008: fig. 16; Wawrusiewicz et al., 2017: pls XVIII.282, XVI.251).

clearly recall the Bell Beaker style but with increasingly strong traits typical of the classic Trzciniec pottery style (Figure 9). A similar phenomenon is also observable in other regions of the Neman cultural circle, that is, in the territories occupied by the Linin and Ząbie-Szestno groups (Manasterski, 2016: 116-20, figs 38-41).

\section{Conclusion}

Feature 30 from Site 6 at Supraśl is a rare example of a ritual practice performed by Late Neolithic hunters-gatherers within a Neman cultural circle environment. Elements of this feature point to a synthesis of rites practised by autochthonous and allochthonous groups. The components of 
the deposit, for the most part extraneous to the local community, are linked to the Bell Beaker cultural set and are a harbinger of innovations that would transform the hunter-gatherers' world. Pottery was the chief vehicle of change. Initial imitations of various kinds were gradually transformed, to become a new syncretic form of vessel. The Bell Beaker component in this pottery was still discernible in the Early Bronze Age.

The Supraśl feature may be considered as the beginning of a process of transforming ritual behaviour. The rites were still performed, albeit with their initial symbolic components lost or modified, in the Early Bronze Age as the Neman cultural circle was fading, and can be traced in the formation of the western branch of the Trzciniec cultural circle. We offer this study as an example of a ritual practice that transcends narrow cultural criteria.

\section{ACKNOWLEDGEMENTS}

We would like to thank all the participants of the excavations in Supraśl and all the reviewers.

\section{REFERENCES}

Budziszewski, J. 2008. Stan badań nad występowaniem i pradziejową eksploatacją krzemieni czekoladowych. In: W. Borkowski, J. Libera, B. Sałacińska \& S. Sałaciński, eds. Krzemień czekoladowy w pradziejach. Materiaty z konferencji w Orońsku, 08-10.10.2003 (Studia nad Gospodarką Surowcami Krzemiennymi w Pradziejach, 7). Warszawa-Lublin: Państwowe Muzeum Archeologiczne w Warszawie, pp. 33-106.

Bugaj, U. 2008. The Bronze Age Settlement from Site 1 in Góra Strękowa, County of Białystok. Sprawozdania Archeologiczne, 60: 169-263.

Bukowski, Z. 2002. Znaleziska bursztynu w zespotach z wczesnej epoki brazu $i$ z wczesnej epoki żelaza z dorzecza Odry i Wisty.
Warszawa: Instytut Archeologii i Etnologii PAN.

Burgess, C. \& Shennan, S.J. 1976. The Beaker Phenomenon: Some Suggestions. In: C. Burgess \& R. Miket, eds. Settlement and Economy in the Third and Second Millennia BC. Oxford: British Archaeological Reports, pp. 309-31.

Burszta, W.J. 1998. Antropologia kultury. Teorie, tematy, interpretacje. Poznań: Wydawnictwo Zysk i S-ka.

Charnyavski, M.M. 1979. Nyealit Byelaruskaba Panyamonnya. Minsk: Navuka i tekhnika.

Charnyavski, M.M. 2011a. Kamyenny oyek Byelarusi. Minsk: Tekhnalohiya.

Charnyavski, M.M. 2011b. Nemanskaya nealitychnaya kul'tura v Belarusi: genezis i evalyutsyya. In: U. Stankiewicz \& A. Wawrusiewicz, eds. Na rubieży kultur. Badania nad okresem neolitu $i$ wczesna epokq brazu. Białystok: Muzeum Podlaskie w Białymstoku, pp. 77-86.

Czebreszuk, J. 2001. Schytek neolitu i poczatki epoki brązu w strefie potudniowo-zachodniobattyckiej (III i poczatki II tys. przed Chr.). Alternatywny model kultury. Poznań: Wydawnictwo Naukowe Uniwersytetu im. Adama Mickiewicza w Poznaniu.

Dąbrowski, J. 1997. Epoka Brazu w PótnocoWschodniej Polsce (Prace Białostockiego Towarzystwa Naukowego 36). Białystok: Białostockie Towarzystwo Naukowe. Instytut Archeologii i Etnologii Polskiej Akademii Nauk.

Garrido-Pena R. 2007. El fenómeno campaniforme: un siglo de debat es sobre un enigma sin resolver. In: C. Cacho, R. Maicas, M.I. Martinez \& I.A. Martos, eds. Acercándonos al pasado: Prehistoria en 4 actos. Madrid: Museo Arqueológico Nacional, pp. 1-16.

Geertz, C. 1992. Religia jako system kulturowy. In: E. Mokrzycki, ed. Racjonalnośc i styl myślenia Warszawa: IFiS PAN, pp. 498-555.

Gręzak, A. 2015. Zwierzęce szczątki kostne ze stanowiska 6 w miejscowości Supraśl, woj. Podlaskie / Animal Osteological Remains from Site 6 in Supraśl, Podlachian Voivodeship. In: A. Wawrusiewicz, K. Januszek \& D. Manasterski. Obiekty obrzędowe Pucharów Dzwonowatych z Supraśla. Z tożenie darów - przejęcie terenu czy integracja kulturowa? / Ritual Features of Bell Beaker in Suprásl. The Offering - 
Taking Possession of the Land or Cultural Integration? Białystok: Muzeum Podlaskie w Białymstoku, p. 247.

Heyd, V. 2007. Families, Prestige Goods, Warriors and Complex Societies: Beaker Groups in the 3rd Millennium cal BC. Proceedings of the Prehistoric Society, 73: 327-80. https://doi.org/10.1017/ S0079497X00000104

Hodder, I. 1987. The Contextual Analysis of Symbolic Meanings. In: I. Hodder, ed. The Archaeology of Contextual Meanings. Cambridge: Cambridge University Press, pp. 1-16.

Hołbowicz, W. 1950. Garncarstwo wiejskie zachodnich terenów Biatorusi (Prace Prehistoryczne 3/4). Torun: Towarzystwo Naukowe w Toruniu.

Insoll, T. 2011. Sacrifice. In: T. Insoll, ed. Oxford Handbook of the Archaeology of Ritual and Religion. Oxford: Oxford University Press, pp. 151-65. https://doi. org/10.1093/oxfordhb/9780199232444.001. 0001

Januszek, K. 2015. Artefakty krzemienne w depozytach obrzędowych społeczności późnego neolitu i wczesnej epoki brązu na Mazowszu i Podlasiu. Studia i Materiaty do Badań nad Neolitem i Wczesna Epoka Brazu na Mazowszu i Podlasiu, 5: 113-27.

Januszek, K. \& Manasterski, D. 2012. Obiekt obrzędowy - depozyt przedmiotów symboliczno-użytkowych społeczności $\mathrm{Z}$ wczesnej epoki brązu w Skrzeszewie, gm. Wieliszew, woj. mazowieckie. Studia $i$ Materiaty do Badán nad Neolitem $i$ Wczesna Epokq Brazu na Mazowszu i Podlasiu, 2: 115-45.

Józwiak, B. 2003. Spotecznósci subneolitu wschodnioeuropejskiego na Niżu Polskim w międzyrzeczu Odry i Wisty (Materiały do syntezy pradziejów Kujaw 11). Poznań: Instytut Prahistorii Uniwersytetu im. Adama Mickiewicza.

Kempisty, A. 1989. Kultury paraneolityczne. In: J. Kieciński, ed. Pradzieje ziem polskich I, 1. Od paleolitu do środkorvego okresu latenskiego. Epoka kamienia. Neolit. WarszawaŁódź: Państwowe Wydawnictwo Naukowe, pp. 301-26.

Kempisty, E. 1973. Kultura ceramiki grzebykowo-dołkowej na Mazowszu i Podlasiu. Wiadomósi Archeologiczne, 38: 3-75.

Kleijne, J. 2019. Embracing Bell Beaker: Adopting New Ideas and Objects Across
Europe During the Later 3rd Millennium $B C$ (2600-2000 BC). Leiden: Sidestone Press.

Kondracki, J. 2002. Geografia regionalna Polski. Warszawa: Wydawnictwo Naukowe PWN.

Kośko, A. \& Szmyt, M. 2004. Problem wschodniej rubieży kultur neolitycznych Niżu Srodkowoeuropejskiego: IV-III tys. BC. In: A. Kośko \& A. Kalyechyts, eds. Wspólnota dziedzictwa kulturowego ziem Biatorusi i Polski. Warszawa: Ósrodek Ochrony Dziedzictwa Archeologicznego, pp. 80-94.

Krajcarz, M. 2015. Ekspertyza petrograficzna zabytków kamiennych ze stanowisk nr 3 i $6 \mathrm{w}$ Supraślu / Petrographic Expertise of Lithic Artefacts from Sites No. 3 and 6 in Supraśl. In: A. Wawrusiewicz, K. Januszek \& D. Manasterski. Obiekty obrzędowe Pucharów Dzwonowatych z Suprásla. Z tożenie darów - przejęcie terenu czy integracja kulturowa? / Ritual Features of Bell Beaker in Supraśl. The Offering - Taking Possession of the Land or Cultural Integration? Białystok: Muzeum Podlaskie w Białymstoku, pp. 253-62.

Kwiatkowska, K. 2015. Analiza surowcowa i technologiczna ozdób bursztynowych / Analysis of the Raw Material and Technology Used to Manufacture Amber Artefacts. In: A. Wawrusiewicz, K. Januszek \& D. Manasterski, eds. Obiekty obrzędowe Pucharów Dzwonowatych z Supraśla. Ztożenie darów - przejęcie terenu czy integracja kulturowa? / Ritual Features of Bell Beaker in Suprasl. The Offering Taking Possession of the Land or Cultural Integration? Białystok: Muzeum Podlaskie w Białymstoku, pp. 325-34.

Kwiatkowski, W. 2015. Środowisko przyrodnicze okolic Supraśla. In: A. Wawrusiewicz, K. Januszek \& D. Manasterski. Obiekty obrzędowe Pucharów Dzwonowatych z Supraśla. Ztożenie darów przejecie terenu czy integracja kulturowa? / Ritual Features of Bell Beaker in Suprásl. The Offering - Taking Possession of the Land or Cultural Integration? Białystok: Muzeum Podlaskie w Białymstoku, pp. 209-23.

Lakiza V.L. 2008. Starazhytnastsi poznyaha nyealitu $i$ rannyaba pyeryyadu bronzavaha vyeku Byelaruskaha Panyamonnya. Minsk: Byelaruskaya navuka.

Liesau von Lettow-Vorbeck, C., Guerra Doce, E. \& Delibes de Castro, G. 2014. Casual or 
Ritual: The Bell Beaker Deposit of La Calzadilla (Valladolid, Spain). Quaternary International, 330: 88-96. https://doi.org/ 10.1016/j.quaint.2013.10.046

Makarowicz, P. 2010. Trzciniecki krag kulturowy - wspólnota pogranicza Wschodu $i$ Zachodu Europy (Archaeologia Bimaris Monografie 3). Poznań: Wydawnictwo Poznańskie.

Makowiecki, D. 2017. Analiza makroskopowa szczątków kostnych ze stanowiska $1 \mathrm{w}$ Grądach-Woniecko, gm. Rutki, woj. podlaskie. In: A. Wawrusiewicz, T. Kalicki, M. Przeździecki, M. Frączek \& D. Manasterski. Grady-Woniecko. Ostatni towcy-zbieracze znad srodkowej Narwi. Białystok: Muzeum Podlaskie w Białymstoku, pp. 287-89.

Manasterski, D. 2009. Pojezierze Mazurskie u schytku neolitu i na początku epoki brązu w świetle zespotów typu Zabie-Szestno. Warszawa: Instytut Archeologii Uniwersytet Warszawski.

Manasterski, D. 2014a. Mazowiecka ceramika z przełomu neolitu i epoki brązu ze zbiorów Państwowego Muzeum Archeologicznego w Warszawie. Studia i Materiaty do Badan nad Neolitem i Wczesna Epoka Brązu na Mazowszu i Podlasiu, 4: 31-56.

Manasterski, D. 2014b. Od "Linina" do "Trzcińca" - wpływ i ewolucja "pucharowej” stylistyki dekoracji naczyń jako przyczynek do badań nad kształtowaniem się społeczności wczesnej epoki brązu na Mazowszu i w Polsce PółnocnoWschodniej. Studia i Materiaty do Badan nad Neolitem i Wczesna Epokq Brąu na Mazorwszu i Podlasiu, 4: 77-109.

Manasterski, D. 2016. Puchary Dzwonowate $i$ ich wptyw na przemiany kulturowe przet omu neolitu i epoki brązu w pótnocnowschodniej Polsce $i$ na Mazowszu w swietle ceramiki naczyniowej (Światowit. Supplement Series P: Prehistory and Middle Ages, 19). Warszawa: Instytut Archeologii Uniwersytet Warszawski.

Manasterski, D. \& Januszek, K. 2017. Relikt symbolicznych zachowań społeczności trzcinieckiego kręgu kulturowego $\mathrm{z}$ miejscowości Pass, gm. Błonie, woj. mazowieckie. Studia i Materiaty do Badán nad Neolitem i Wczesna Epoka Brazu na Mazowszu i Podlasiu, 7: 81-96.

Manasterski, D., Januszek, K., Wawrusiewicz, A. \& Klecha, A. In press. Bell Beaker
Cultural Package in the East European Periphery of the Phenomenon: A Case of Ritual Features in North-eastern Poland. Documenta Praebistorica.

Mazurowski, 1983. Bursztyn w epoce kamienia na ziemiach polskich. Materiaty Starożytne i Wczesnósredniowieczne, 5: 7-134.

Michniewicz, M. 2012. Wyniki ekspertyzy botanicznej próbki organicznej ze stanowiska nr AZP 52-65/49 w Skrzeszewie, gm. Wieliszew, woj. mazowieckie, wykop 2, obiekt 1. Aneks 1. Studia i Materiaty do Badań nad Neolitem i Wczesna Epokq Brazu na Mazorwszu i Podlasiu, 2: 147.

Minta-Tworzowska, D. 2012. Źródło/Ślad/ Artefakt/Rzecz/Przedmiot. In: S. Tabaczyński, A. Marciniak, D. Cyngot \& A. Zalewska, eds. Przeszt ość spoteczna. Próba konceptualizacji. Poznań: Wydawnictwo Poznańskie, pp. 137-61.

Nicolas, C. 2017. Arrows of Power from Brittany to Denmark (2500-1700 BC). Proceedings of the Prehistoric Society, 83: 247-87. https://doi.org/10.1017/ppr.2017.5

Orphanides, A.G. 1990. A Theoretical Approach for the Interpretation of Archaeological Material. Archaeologia Cypria, 2: 11-19.

Pietrzak, S. 2015. Analiza substancji zachowanych na powierzchni ścianek naczyń odkrytych na stanowisku 3 i 6 w Supraślu / Analysis of the Residues of Organic Substances Preserved on the Wall Surfaces of Pottery Vessels from Sites 3 and 6 in Supraśl. In: A. Wawrusiewicz, K. Januszek \& D. Manasterski. Obiekty obrzędowe Pucharów Dzwonowatych z Supraśla. Ztożenie darów - przejęcie terenu czy integracja kulturowa? / Ritual Features of Bell Beaker in Suprasl. The Offering - Taking Possession of the Land or Cultural Integration? Białystok: Muzeum Podlaskie w Białymstoku, pp. 297-312.

Pietrzak, S. 2017. Fragmenty naczyń ze śladami smół drzewnych ze stanowiska 1 w Grądach-Woniecko, gm. Rutki, woj. podlaskie. In: A. Wawrusiewicz, T. Kalicki, M. Przeździecki, M. Frączek \& D. Manasterski. Grady-Woniecko. Ostatni towcy-zbieracze znad środkowej Narwi. Białystok: Muzeum Podlaskie w Białymstoku, pp. 308-15.

Popkiewicz, E. 2016. Jakimi sposobami i narzędziami obrabiano paciorki 
bursztynowe $\mathrm{z}$ obiektów obrzędowych Pucharów Dzwonowatych z Supraśla. Studia i Materiaty do Badańn nad Neolitem i Wczesna Epoka Brazu na Mazorwszu i Podlasiu, 7: 53-63.

Pyżewicz, K. 2015. Wyniki analizy traseologicznej / Results of Use-Wear Analyses. In: A. Wawrusiewicz, K. Januszek \& D. Manasterski. Obiekty obrzędowe Pucharów Dzwonowatych z Suprásla. Ztożenie darów - przejęcie terenu czy integracja kulturowa? I Ritual Features of Bell Beaker in Suprásl. The Offering - Taking Possession of the Land or Cultural Integration? Białystok: Muzeum Podlaskie w Białymstoku, pp. 297-312.

Renfrew, C. 1994. The Archaeology of Religion. In: C. Renfrew \& E.B.W. Zubrow, eds. The Ancient Mind: Elements of Cognitive Archaeology. Cambridge: Cambridge University Press, pp. 47-54.

Renfrew, C. 2001. Archeologia $i$ jezzyk. Warszawa-Poznań: Wydawnictwo Naukowe PWN SA.

Renfrew, C. \& Bahn, P. 1991. Archaeology: Theories, Methods and Practice. London: Thames \& Hudson.

Rosiak, A. \& Kałużna-Czaplińska, J. 2015. Analiza substancji organicznych zachowanych na powierzchni ścianek naczyń odkrytych na stanowisku 3 i 6 w Supraślu / Analysis of Organic Substances Preserved in the Ceramic Mass. In: A. Wawrusiewicz., K. Januszek \& D. Manasterski. Obiekty obrzędowe Pucharów Dzwonowatych z Suprásla. Ztożenie darów przejecie terenu czy integracja kulturowa? / Ritual Features of Bell Beaker in Supraśl. The Offering - Taking Possession of the Land or Cultural Integration? Białystok: Muzeum Podlaskie w Białymstoku, pp. 273-82.

Schild, R., Marczak, M. \& Królik, H. 1975. Póziny mezolit. Próba wieloaspektowej analizy otwartych stanowisk piaskowych. Wrocław, Warszawa, Kraków \& Gdańsk: Zakład Narodowy Imienia Ossolińskich, Wydawnictwo Polskiej Akademii Nauk.

Shennan, S. 1986. Central Europe in the Third Millennium BC: An Evolutionary Trajectory for the Beginning of the European Bronze Age. Journal of Anthropological Archaeology, 5: 115-46. https://doi.org/10.1016/02784165(86)90011-5
Turek, J. 2013. Echoes and Traditions of the Bell Beaker Phenomenon. In: M. Bartelheim, J. Peška \& J. Turek, eds. From Copper to Bronze: Cultural and Social Transformations at the Turn of the 3rd/2nd Millennia BC in Central Europe. Gewidmet PhDr. Václav Moucha, CSc. anlässlich seines 80. Geburtstages (Beiträge zur Ur- und Frühgeschichte Mitteleuropas 74). Langenweißbach: Beier \& Beran, pp. 9-23.

Wawrusiewicz, A. 2011. Okres neolitu i wczesnej epoki brązu na Podlasiu. Stan i perspektywy badań. In: U. Stankiewicz \& A. Wawrusiewicz, eds. Na rubieży kultur. Badania nad okresem neolitu i wczesna epokq brazu. Białystok: Muzeum Podlaskie w Białymstoku, pp. 13-36.

Wawrusiewicz, A., Januszek, K. \& Manasterski, D. 2015. Obiekty obrzędowe Pucharów Dzwonowatych z Suprásla. Ztożenie darów przejecie terenu czy integracja kulturowa? / Ritual Features of Bell Beaker in Suprásl. The Offering - Taking Possession of the Land or Cultural Integration? Białystok: Muzeum Podlaskie w Białymstoku.

Wawrusiewicz, A., Kalicki, T., Przeździecki, M., Frączek, M. \& Manasterski D. 2017. Grądy-Woniecko. Ostatni towcy-zbieracze znad 'srodkowej Narwi. Białystok: Muzeum Podlaskie w Białymstoku.

Więckowski, W. 2017. Analiza antropologiczna szczątków kostnych ze stanowiska 1 w Grądach-Woniecko, gm. Rutki, woj. podlaskie. In: A. Wawrusiewicz, T. Kalicki, M. Przeździecki, M. Frączek \& D. Manasterski. Graqdy-Woniecko. Ostatni towcy-zbieracze znad środkowej Narwi. Białystok: Muzeum Podlaskie w Białymstoku, p. 286.

\section{Biographical Notes}

Dariusz Manasterski is Assistant Professor at the Department of Prehistoric Archaeology at the Institute of Archaeology of the University of Warsaw. His interests include long-distance contacts and cultural interactions in the European Neolithic and Early Bronze Age. His research focuses on the border zone of the Central and Eastern European Plains and in the interactions 
between local hunter-gatherer communities and extraneous farming and pastoralist societies, with pottery as one of the main identifiers of past behaviours and cultural processes.

Address: Institute of Archaeology, University of Warsaw, Krakowskie Przedmieście St. 26/28, 00-927 Warsaw, Poland. [email: dmanasterski@uw.edu.pl]. ORCID https://orcid.org/0000-00020246-4795

Katarzyna Januszek is a lecturer at the Department of Prehistoric Archaeology of the Institute of Archaeology of the University of Warsaw, specializing in flint in the Neolithic and Early Bronze Age. Her interests include the regions of the Central and Eastern European Plains.

Address: Institute of Archaeology, University of Warsaw, Krakowskie Przedmieście St. 26/28, 00-927 Warsaw, Poland. [email: katarzyna.januszek@uw. edu.pl]. ORCID https://orcid.org/00000001-7355-3827

Adam Wawrusiewicz is an employee of the Podlaskie Museum in Białystok. His research is focused on the eastern borderlands of Poland and the Central and Eastern European Plains, with a special interest in the sub-Neolithic hunter-gatherer communities of the Neman culture.

Address: Podlaskie Museum in Białystok, Kościuszki Square no. 10, 15-426 Białystok, Poland. [email: adamwawrusiewicz@op.pl]. ORCID https://orcid.org/ 0000-0002-2887-387X

Aleksandra Klecha is a $\mathrm{PhD}$ candidate at the Antiquity of South-Eastern Europe Research Centre of the University of Warsaw; her doctoral dissertation focuses on the application of interdisciplinary research to identifying cultural transformation from the Neolithic to the Bronze Age at the edge of the Central and Eastern European Plains. She has participated in archaeological investigations in Poland, Russia, and Belarus.

Address: Antiquity of South-Eastern Europe Research Centre, University of Warsaw, 017 Krakowskie Przedmieście 32, 00-927 Warsaw, Poland. [email: aleksandraaklecha@gmail.com]. ORCID https://orcid.org/0000-0002-6131-9889

\section{Une structure rituelle avec éléments campaniformes dans un camp de chasseurs- cueilleurs du Néolithique Final en Pologne nord-orientale}

La nature éphémère des pratiques religieuses et des cérémonies rituelles les rend difficile à appréhender parmi les données archéologiques relatives aux chasseurs-cueilleurs du Néolithique Final en Europe centrale et orientale. Une structure rituelle contenant des éléments campaniformes découverte dans le nordest de la Pologne, une région occupée par des groupes de chasseurs-cueilleurs appartenant à la culture de Neman, constitue une exception. Son caractère syncrétique présage des transformations culturelles plus amples menant à l'émergence à l'âge du Bronze du groupe occidental de la culture de Trzciniec dans cette région. Translation by Madeleine Hummler

Mots-clés: Néolithique Final, chasseurs-cueilleurs, structure rituelle, ensemble campaniforme, Pologne du nord-est, culture de Neman, culture de Trzciniec 


\section{Eine rituelle Struktur mit Glockenbecherelementen auf einer spätneolithischen Jäger und Sammler Stätte in Nordost-Polen}

Der flüchtige Charakter der religiösen Praktiken und Riten machen es schwer, solche Erscheinungen in den archäologischen Befunden der spätneolitbischen Jäger und Sammler Gesellschaften in Zentral- und Osteuropa zu erfassen. Eine rituelle Struktur mit Glockenbecherelementen in Nordost-Polen, ein Gebiet, das von Jäger und Sammler Gruppen des Neman Kulturkreises besiedelt war, ist deswegen eine Ausnahme. Der synkretistische Charakter dieses Befundes kündigt weitere kulturelle Veränderungen an, welche zur Entstehung des westlichen Trzciniec Kulturkreises in der Bronzezeit führte. Translation by Madeleine Hummler

Stichworte: Spätneolithikum, Jäger und Sammler, rituelle Struktur, Glockenbecher Satz, NordostPolen, Neman Kulturkreis, Trzciniec Kulturkreis 